\title{
Levels of Some Heavy Metals and Physico Chemical Properties of Effluents from a Beverage Company in Rivers State, Nigeria
}

\author{
AKANINWOR, J O; WEGWU, M O.; *NWAICHI, E O \\ Department of Bioichemistry, University of Port Harcourt, Choba, P.M.B. 5323. Port Harcourt. Rivers State, Nigeria.
}

\begin{abstract}
In this study, the concentrations of selected heavy meyals and physico-chemical characteristics of effluents from a beverage company in Rivers State, Nigeria and those of the receiving Woji River were evaluated to ascertain the efficiency of the company's waste treatment processes. The results showed that the contents of $\mathrm{Mg}$ in downstream water samples differed significantly $(\mathrm{p}<0.05)$ from those of upstream and effluent samples with a value of $80.8 \mathrm{mg} / \mathrm{l}$. However, the concentration of $\mathrm{Na}^{+}$in the upstream samples far exceeded those of other samples with a mean value of $791 \mathrm{mg} / \mathrm{l}$. The concentrations of $\mathrm{Cd}, \mathrm{Pb}$ and $\mathrm{Cr}$ fell below detection limit of $0.001 \mathrm{mg} / \mathrm{l}$ for all samples. Also, the levels of Fe, Zn, and Mn were low with Fe having the highest concentration of $2.10 \mathrm{mg} / \mathrm{l}$ (downstream and treated effluent samples, respectively). The $\mathrm{pH}$ of the samples were generally alkaline, except the upstream samples that gave a $\mathrm{pH}$ value of 6.89. The dissolved Oxygen contents of all the samples fell below FEPA limit of $10 \mathrm{mg} / \mathrm{l}$. However, the highest chemical oxygen demand concentration of $93.7 \mathrm{mg} / \mathrm{l}$ was obtained in the untreated effluent sample. The mean ammonia concentration of the untreated sample was much higher than those of the treated with a value of $50.0 \mathrm{mg} / \mathrm{l}$. Also, total dissolved solid content of the untreated sample fell far above those of the treated sample. In general, whereas the concentrations of nutrient metals were higher in the treated samples, the contents of the physico-chemical parameters in the treated samples fell far below those of the untreated samples. These findings suggest that the treatment system adopted by the beverage company is efficient for effluent treatment as the values fell within the natural background levels. @JASEM
\end{abstract}

Effluents are liquid waste materials that are by products of human activities such as liquid industrial discharge or sewage (ISO 14001, 2000). Nature has an amazing ability to cope with small amounts of water wastes and pollution, but it would be dangerous or detrimental if the billions of gallons of waste water and sewage produced every day are not treated before releasing them back to the environment. Treatment plants reduce pollutants in waste water to a level nature can handle. Our water should be kept clean for the purposes of its use in the fishing industry, sports, wild life habitats, recreation, and health concerns (Kakulu and Osibanjo, 1991). Whenever industrial wastewater is discharged into a body of surface water, care must be taken to avoid damaging any sensitive ecosystem and to ensure that no long term accumulation of pollutants occurs in the sediments and that the overall use of the water in question is not impaired. Untreated or incompletely treated industrial wastewater contains algae materials, non biodegradable organic matter, heavy metals and other toxicants that deteriorate the receiving stream( Adeyinka, 1996). Biodegradable pollutants constitute those that can be broken by micro-organisms and hence their effects are short - lived in the environment. Problems set in when input into the environment exceeds the environment capacity/threshold to decompose. Non-biodegradable pollutants are those that cannot be broken down by micro-organisms and hence persist in the environment and become toxic to life e.g. heavy metals such as $\mathrm{Hg}, \mathrm{Pb}, \mathrm{Cd}, \mathrm{Cr}, \mathrm{V}$, etc and compounds like DOT, HCFC, CFC, pesticides etc. They accumulate in living tissue and proceed along the food chain and could result in the death of organisms (Horsfall and Spiff, 1998). The $\mathrm{pH}$ of natural water determines the solubility and chemical forms of most substances in water. Also, high levels of total dissolved solids limits the industrial and agricultural use of water (Asa - Asare, 1992). High total suspended solids levels also increases turbidity in water which prevents light from reaching aquatic plants and animals (Kakulu and Osibanjo, 1991). Nitrates, organic wastes and oil reduces dissolved oxygen by increasing biological oxygen demand and this can inhibit aquatic flora and fauna growth (Sharon, 1994). By a similar action to that of $\mathrm{Ca}, \mathrm{Mg}$ imparts hardness to water. This may be reduced by chemical softening or by ion exchange (APHA, 1992). The aim of this work was to ascertain the levels of heavy metals and physico - chemical parameters in effluents from a beverage company in River State of Nigeria and those of the receiving Woji River.

\section{MATERIALS AND METHODS}

Collection of Samples: Effluent samples were collected from effluent collection and discharge tanks of the beverage company's effluent treatment plant, respectively. Samples for dissolved oxygen (DO) and biochemical oxygen demand (BOD) were obtained using a wide - mouth $500 \mathrm{ml}$ sample bottle. Similarly, upstream and downstream water samples from the receiving Woji river were collected using the sample bottles earlier described. Also, both effluent and water samples for dissolved heavy metals were collected using 1.51 pre - cleaned plastic sample bottles and acidified to $\mathrm{pH} 2$ with concentrated $\mathrm{HCl}$. 
The samples were collected in triplicates and immediately transported to the laboratory for analysis.

Determination of Selected Parameters: $\mathrm{pH}$ and temperature of effluents and river water were estimated directly in the effluent collection and discharge tanks and in the river with the aid of a micro $\mathrm{pH}$ and micro thermometer. The estimation of chemical oxygen demand (COD), total nitrogen, BOD and DO were performed using reagent kits as described by Chapman(1996). Thus, DO of effluent and water samples were obtained using Hana DO meter H19142 while Hana BOD system oxidirect kit was employed in the determination of $\mathrm{BOD}_{5}$ after incubation of sample for 5 days at $20^{\circ} \mathrm{C}$. Similarly, COD and total nitrogen in the samples were obtained using Hana C214 multiparameter bench photometer as described in procedural manual. A digital total dissolved solids tester with automatic temperature compensation (ATC) was employed in the estimation of TDS in the effluent and water samples. Determination of nitrate, sulphate, phosphate and nitrite concentrations in the samples was carried out using a UV spectrophotometer (1608 Shimadzu model) as described by APHA (1992). The concentrations of heavy metals in the samples were obtained using Buck Scientific Atomic Absorption /Emission Spectrophotometer (Model 200A).
Analysis of Data: Data were treated by analysis of variance (ANOVA). Significance was accepted at the $\mathrm{P} \leq 0.05$ level.

\section{RESULTS AND DISCUSSION}

The results for the heavy metals concentration in the upstream, downstream, generated and the treated effluent samples is as shown in Table $1 . \mathrm{Cd}, \mathrm{Pb}$ and $\mathrm{Cr}$ were not detected. Table 2 shows the results obtained for the physico - chemical parameters in the samples. Nitrites were not detected in all samples except for untreated effluent, $\mathrm{PO}_{4}{ }^{2-}$ levels fell below the detection limit of the analytical instrument used. Chloride levels showed no marked variation between the effluent samples and between the upstream and downstream samples and fell above WHO limit of $200 \mathrm{mg} / \mathrm{l}$. The temperature for all samples were relatively uniform throughout the study period and ranged from $30.5-39.0\left({ }^{\circ} \mathrm{C}\right)$. The total nitrogen and ammonia levels for downstream samples fell below the detection limit of the analytical instrument and differed significantly for effluent samples. The temperature recorded in this study did not exceed the Department of Petroleum Resources (DPR) limit of $35^{\circ} \mathrm{C}$. TDS values fell below FEPA maximum limits of $2000 \mathrm{mg} / \mathrm{l}$. The dissolved solids and the suspended solids play significant roles in the water quality index for the total solids at the different stations (Chindah and Pudo, 1991).

Table 1: Mean concentrations ( $\mathrm{mg} / \mathrm{l}$ ) and ranges (in parenthesis) of selected heavy metals in the samples

\begin{tabular}{|c|c|c|c|c|c|c|c|c|c|c|}
\hline Sample & $\mathrm{Mg}$ & $\mathrm{Na}$ & $\mathrm{Cd}$ & $\mathrm{Pb}$ & $\mathrm{Fe}$ & $\mathrm{Zn}$ & $\mathrm{Mn}$ & $\mathrm{Cr}$ & $\mathrm{K}$ & $\mathrm{Ca}$ \\
\hline Upstream & $\begin{array}{c}0.58 \pm 0.12^{\mathrm{b}} \\
(0.44-0.73)\end{array}$ & $\begin{array}{r}791 \pm 0.57^{\mathrm{a}} \\
(790-791)\end{array}$ & ND & ND & $\begin{array}{l}0.26 \pm 0.03^{b} \\
(0.22-0.28)\end{array}$ & $\begin{array}{c}0.03 \pm 0.32^{\mathrm{b}} \\
(0.01-0.07)\end{array}$ & $\begin{array}{l}0.26 \pm 0.03^{\mathrm{a}} \\
(0.04-0.42)\end{array}$ & ND & $\begin{array}{l}36.1 \pm 0.03^{\mathrm{a}} \\
(36.0 \pm 36.1)\end{array}$ & $\begin{array}{c}16.7 \pm 0.01^{\mathrm{b}} \\
(16.7-16.7)\end{array}$ \\
\hline Downstream & $\begin{array}{l}80.8 \pm 0.44^{\mathrm{a}} \\
(80.3-81.3)\end{array}$ & $\begin{array}{l}32.1 \pm 0.71^{\mathrm{b}} \\
(31.3-33.0)\end{array}$ & ND & ND & $\begin{array}{l}2.10 \pm 0.07^{\mathrm{a}} \\
(2.00-2.15)\end{array}$ & $\begin{array}{l}0.01 \pm 0.01^{\mathrm{b}} \\
(0.01-0.02)\end{array}$ & $\begin{array}{c}0.20 \pm 0.02^{\mathrm{c}} \\
(0.18-0.22)\end{array}$ & ND & $\begin{array}{c}3.53 \pm 0.08^{\mathrm{b}} \\
(3.45-3.63)\end{array}$ & $\begin{array}{l}4.81 \pm 0.05^{\mathrm{d}} \\
(4.78-4.88)\end{array}$ \\
\hline $\begin{array}{l}\text { Untreated } \\
\text { Effluent }\end{array}$ & $\begin{array}{l}0.14 \pm 0.02^{\mathrm{b}} \\
(0.12-0.17)\end{array}$ & $\begin{array}{l}176 \pm 0.04^{\mathrm{c}} \\
(176.3-176.4)\end{array}$ & $\begin{array}{l}\mathrm{ND} \\
{ }_{1}\end{array}$ & ND & $\begin{array}{l}1.14 \pm 0.04^{\mathrm{c}} \\
(1.10-1.20)\end{array}$ & $\begin{array}{l}0.07 \pm 0.01^{\mathrm{c}} \\
(0.07-0.08)\end{array}$ & $\begin{array}{l}0.02 \pm 0.01^{\mathrm{b}} \\
(0.01-0.03)\end{array}$ & ND & $\begin{array}{l}4.12 \pm 0.01^{\mathrm{c}} \\
(4.11-4.14)\end{array}$ & $\begin{array}{l}1.72 \pm 0.01^{\mathrm{c}} \\
(1.70-1.73)\end{array}$ \\
\hline $\begin{array}{l}\text { Treated } \\
\text { Effluent }\end{array}$ & $\begin{array}{l}0.32 \pm 0.08^{\mathrm{b}} \\
(0.22-0.41)\end{array}$ & $\begin{array}{l}270.6 \pm 0.09^{\mathrm{d}} \\
(271-272)\end{array}$ & ND & ND & $\begin{array}{l}2.10 \pm 0.02^{\mathrm{a}} \\
(2.07-2.12)\end{array}$ & $\begin{array}{c}0.04 \pm 0.02^{\mathrm{b}} \\
(0.02-0.05)\end{array}$ & $\begin{array}{c}0.05 \pm 0.01^{\mathrm{b}} \\
(0.03-0.06)\end{array}$ & ND & $\begin{array}{c}5.33 \pm 0.22^{\mathrm{d}} \\
(5.07-5.60) \\
\end{array}$ & $\begin{array}{l}5.31 \pm 0.02^{\mathrm{a}} \\
(5.30-5.33)\end{array}$ \\
\hline
\end{tabular}

*Values are means \pm S.E for 3 samples ( $n=3$ ); *Means in the same column with same superscript letters (a-d) are nor significantly different at the 0.05 level; $* N D=$ Not Detected

The BOD for the treated effluent is safe as it is less than FEPA maximum limit of $10 \mathrm{mg} / 1$ while those of other samples are higher than the limit but there is a clear indication that the effluent discharge into the river is not responsible for the organic pollution of the Woji river. Dumping of sewage and domestic waste into the river by the natives may have influenced the observed BOD levels in the study. The low levels seen in DO for the samples can be attributed to: organic materials which use up oxygen as they are degraded: reducing agents that deplete oxygen resources as they are chemically oxidized: oil and grease that inhibit the transfer of oxygen from the atmosphere in the water body and: surfactants that affect oxygen transfer into water (Eneh, 1994). The presence of phosphate in the effluent samples could be attributed to the dosing of Urea in the Urea dosing tank in the effluent treatment plant of the 
company which may have influenced the levels of nitrogen and phosphorus obtained in this study. Urea is rich in nitrogen and phosphates and hazards such as rapid aging of river bodies, a process known as eutrophication is traceable to the abundance of $\mathrm{N}$ and $\mathrm{P}$ in the water body. Nitrate levels were below the WHO recommended concentration of $50 \mathrm{mg} / 1$. Nitrate determination helps in the assessment of the character and degree of oxidation in surface waters and in biological processes (ISO, 1990). Except for the upstream of the river, samples gave Fe levels higher than WHO maximum / allowable concentration of $1.0 \mathrm{mg} / \mathrm{l}$. The abundance of $\mathrm{Fe}$ in effluent sample may be, in part, due to corrosion encountered as use is made of galvanized pipes in treatment plant. Moreover, the abundance of these metals in samples may have been contributed by run - off water. Ca and $\mathrm{Mg}$ contribute to total hardness of water therefore the samples in this study may be regarded as water free from hardness. $\mathrm{Na}$ level in the upstream of the river gave high values. This could be as a result of the activities of shipping, construction and oil companies in the river.. Na imparts salty taste to drinking water. High ratio of $\mathrm{Na}$ ions to total cations harm permeability of agricultural soil (APHA, 1992). $\mathrm{Zn}, \mathrm{Mg}$ and $\mathrm{K}$ levels recorded fell within normal range in all samples.

Table 2: Mean levels (mg/l) and ranges (in parenthesis) of some physico-chemical parameters in the samples

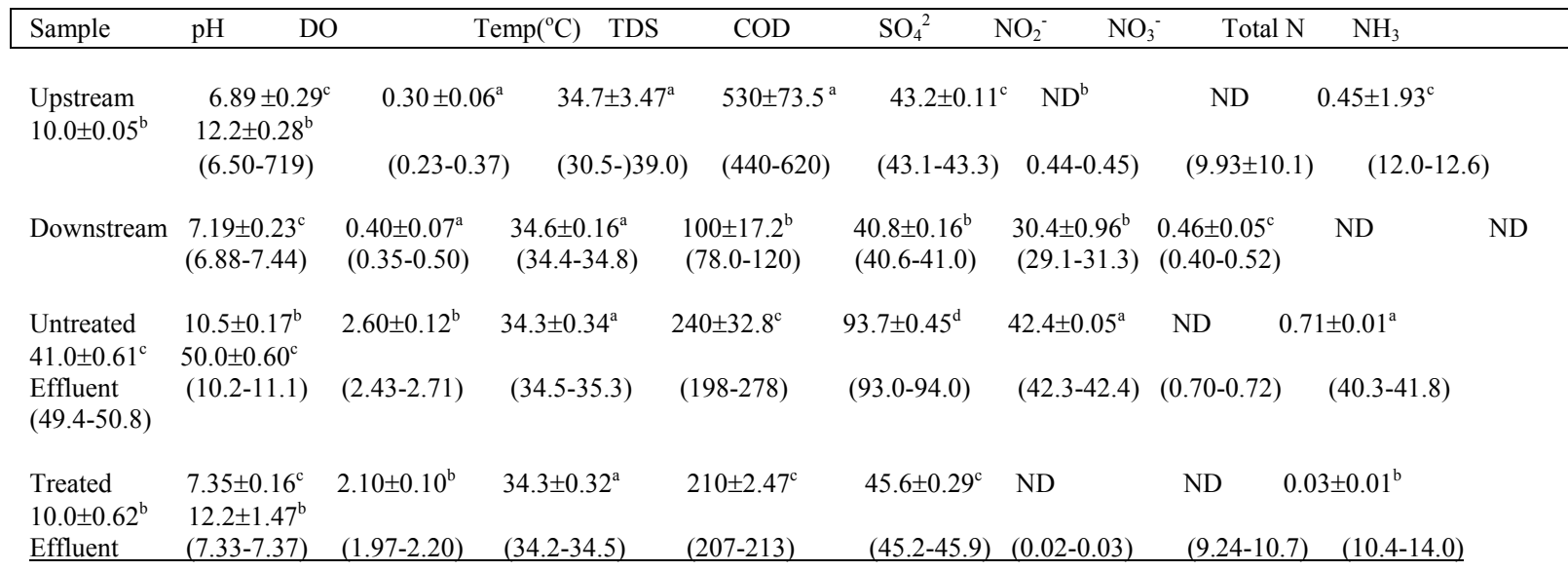

$*$ Values are means \pm S.E for 3 samples $(n=3)$; *Means in the same column with same superscript letters (a-d) are nor significantly different at the 0.05 level; *ND $=$ Not Detected

The structural role of metals is chiefly to neutralize negative charges of anions, free carboxylic acids, nucleic acids and pectic substances. Apart from $\mathrm{Zn}$, treated effluent had higher concentrations of metal in this study than the untreated one. This could be linked to the reagents/additives employed during effluent treatment. Generally, the results in the study indicate that our reference effluent is slightly contaminated and that the treatment plant as evidenced in phosphate elimination, is an efficient one. However, some modifications with the changing trend in technology would enhance the efficiency of the treatment method. The effluent under study contributed little to the contamination of Woji River.

Acknowledgement: The authors are grateful to Dr. Silva of Central Research Laboratory - CMUL, Lagos; Mr. Japhet of Central Research Laboratory, University Of Port Harcourt and Mr. Emeka of Quality Assurance Laboratory of Nigerian Bottling
Company, Port Harcourt Plant for their contributions during the analyses.

\section{REFERENCES}

Adeyinka, J S (1996). Waste water treatment through reverse osmosis. Env. Monitoring and Assessment. 22-37.

Adinna, E N ;Ekop, O B and Attah, V I (2003). Environmental pollution and management in the tropics. Metroprints Publishers - Uyo. 12 -21.

Ansa - Asare, O D (1992). Chemical Characterization and water quality assessment of Densu. Institure of Aquatic

Biology (Council for Scientific and Industrial Research). Tech. 10-23.

APHA. (1992). Standard methods for the examination of water and waste water, $18^{\text {th }} \mathrm{Ed}$. American public health association (APHA), 
American water works association (AWWA), water pollution control federation (WPCF), Washington, DC.66-71.

Chindah, A C; Aduaobo, L H; Braide, SA ; Amadi, A (1993). The epiphytic algal community of the Bonny estuary, Niger Delta. Nigeria. Acta. hydro. biol. 35(4). 307-320.

Eneh, E N (1994). Oil and the environment in Nigeria; The shape of an environmental policy. OPEC BULLETIN. 25 (28): 20-22.

Horsfall, M Jnr; Spiff, I A (1998). Principles of Eviron. Chem. Metroprints Ltd, Port Harcourt, Nigeria. 30-62.

ISO. (1990). Water quality- determination of Nitrate Part 1: 2,6 - Dimethyl Phenol Spectrometric Method. Intl. Std. ISO 7980-1, Intl. Org. fror Standardization, Geneva. 7-42.
ISO 14001. (2000). Petroleum and Natural Gas industries - Offshore productioninstallations- Guidelines on tools and techniques for hazards identification and risk assessment. Intl. Org. for standardization, Geneva. 11 -24.

Kakulu, S E; Osibanjo, O (1991). Pollution Studies of the Nigerian Rivers. Trace metal levels of surface water in the Niger Delta area. Intl.J. Environ. Stud. Anal. Chem; 30: 209-17.

Nwaichi, E O (2002). Compendium of chemical Analytical Methods commonly used in the Central Research Laboratory. Afaide Publishers. Uyo. 9-33.

Sharon, L K (1994). Annual Book of ASTM Standards (Water and Environmental Technology). Vol 11.01. 5-7. 